may help clinicians make better decisions in the effort to become victorious over SARS-CoV-2.

\section{Acknowledgments. None.}

Financial support. This work was supported by the Research Fund of Emergency Project of Prevention and Control for COVID-19 of Central South University (grant no. 160260003).

Conflicts of interest. All authors report no conflicts of interest related to this work.

\section{References}

1. Laboratory testing for coronavirus disease 2019 (COVID-19) in suspected human cases. World Health Organization website. https://www.who.int/ publications-detail/laboratory-testing-for-2019-novel-coronavirus-in-suspectedhuman-cases-20200117. Published 2020. Accessed April 8, 2020.

2. Shi $\mathrm{H}$, Han $\mathrm{X}$, Jiang $\mathrm{N}$, et al. Radiological findings from 81 patients with COVID-19 pneumonia in Wuhan, China: a descriptive study. Lancet Infect Dis 2020;20:425-434.

3. Chan JF, Yip CC, To KK, et al. Improved molecular diagnosis of COVID-19 by the novel, highly sensitive and specific COVID-19-RdRp/Hel real-time reverse transcription-polymerase chain reaction assay validated and with clinical specimens. J Clin Microbiol 2020 Mar 4 [Epub ahead of print]. doi: 10.1128/JCM.00310-20.

4. The diagnosical and therapeutic scheme for COVID-19 (trial version 7). National Health Commission of the Peoples Republic of China website. http://www.nhc.gov.cn/xcs/zhengcwj/202003/46c9294a7dfe4cef80dc7f 5912eb1989.shtml. Published 2020. Accessed April 8, 2020.

5. Xiao MF, Liu XQ, Ji JK, et al. Multiple approaches for massively parallel sequencing of HCoV-19 genomes directly from clinical samples. bioRxiv 2020. doi: $10.1101 / 2020.03 .16 .993584$

6. Zhao J,Yuan Q,Wang $\mathrm{H}$, et al. Antibody responses to SARS-CoV-2 in patients of novel coronavirus disease 2019. Clin Infect Dis 2020 [Epub ahead of print]. doi: 10.1093/cid/ciaa344.

7. Chen $\mathrm{Y}$, Chan $\mathrm{KH}$, Hong $\mathrm{C}$, et al. A highly specific rapid antigen detection assay for on-site diagnosis of MERS. J Infect 2016;73:82-84.

8. Diao B, Wen K, Chen J, et al. Diagnosis of acute respiratory syndrome coronavirus 2 infection by detection of nucleocapsid protein. medRxiv 2020. doi: $10.1101 / 2020.03 .07 .20032524$.

9. Xu X, Yu C, Qu J, et al. Imaging and clinical features of patients with 2019 novel coronavirus SARS-CoV-2. Eur J Nucl Med Mol Imaging 2020;47:1275-1280.

10. Peng QY, Wang XT, Zhang LN. Findings of lung ultrasonography of novel corona virus pneumonia during the 2019-2020 epidemic. Intensive Care Med 2020 Mar 12 [Epub ahead of print]. doi: 10.1007/s00134-020-05996-6.

\title{
Iran's success in controlling the COVID-19 pandemic
}

\author{
Nima Mohammadzadeh $\mathrm{PhD}^{1,2}$ (1), Mahla Shahriary $\mathrm{PhD}^{3}$ and Erfan Nasri MSc ${ }^{4}$ \\ ${ }^{1}$ Department of Microbiology, Faculty of Science, Shahid Beheshti University, Tehran, Iran, ${ }^{2}$ Student Research Committee, Iran University of Medical Sciences, \\ Tehran, Iran, ${ }^{3}$ Department of Microbiology, Tarbiat Modares University of Medical Sciences, Tehran, Iran and ${ }^{4}$ Student Research Committee, School of Medicine, \\ Guilan University of Medical Sciences, Rasht, Iran
}

To the Editor-Coronavirus disease 2019 (COVID-19) is a respiratory tract infection ranging from mild respiratory illness (eg, respiratory symptoms, cough, fever, shortness of breath and breathing difficulties) to severe illness (eg, pneumonia, severe acute respiratory syndrome, kidney failure, and death $)^{1}$ that has caused an unprecedented global crises in $<90$ days in all 206 countries of the world. ${ }^{2}$ Today, most of the world's major cities are in full quarantine and all social and economic behaviors have been limited due to the SARS-Cov-2 outbreak. Controlling the spread of the virus has become one of the most important challenges for governments across the globe. The increase in COVID-19 cases in the advanced industrial countries, including Italy, Germany, France, Spain, and United States, reflects the rapid spread of the virus. As of April 4, 2020, the following countries have been most affected: Italy, with a populations of almost 60 million, has $~ 119,827$ COVID-19 patients (case fatality rate [CFR], 12.25\%). Germany, with a population of almost 82 million, has $~ 85,778$ COVID-19 patients (CFR, 1.34\%). France, with a population of almost 66 million, has $\sim 63,536$ COVID-19 patients (CFR, 10.21\%). Spain, with a population of almost 46 million, has $\sim 117,710$ patients (CFR, 9.28\%). And the United States, with a population of 320 million, has $\sim 241,703$ patients (CFR, 2.42\%). The prevalence of SARS-CoV-2 is rapidly increasing.

Author for correspondence: Nima Mohammadzadeh, E-mail: nima.mz1111@gmail. com or mohammadzadeh.n@iums.ac.ir.

Cite this article: Mohammadzadeh N, Shahriary M, and Nasri E. (2020). Iran's success in controlling the COVID-19 pandemic. Infection Control \& Hospital Epidemiology, 41: 1359-1360, https://doi.org/10.1017/ice.2020.169
Iran, with a population of almost 81 million, has $~ 44,605$ COVID-19 patients, with 2,898 deaths (Fig. 1). Although Iran has been heavily sanctioned in all fields of industry and pharmacy, it has taken important steps from the earliest days of the outbreak to combat the virus. ${ }^{3}$

For example, Italy, with an outbreak date similar to that of Iran, has more than twice the disease incidence rate of Iran. According to reports released by the ministries of health in Iran and Italy, ${ }^{4,5}$ Iran formed a headquarters for the COVID-19 crisis on February 23, when the virus count was $\sim 15$ people per day. In contrast, in Italy, the COVID-19 crisis headquarters was formed on March 13, when the outbreak count was $\sim 2,500$ per day. Also, these countries' respective health ministries published safety and prevention guidelines for many locations, especially crowded centers including hospitals, clubs, transportation systems, schools, etc, in the early days of the outbreak. They also sought widespread collaboration with NGOs and volunteers as well as extensive intragovernmental collaboration to ensure the observation of safety protocols to control the spread of disease. Although traffic and concentration laws as well as heavy fines were not considered in the early days, these collaborations ultimately resulted in an $80 \%$ reduction in traffic between cities and as well as in social gatherings and even family gatherings. Ultimately, all of these measures have led Iran to better control the spread of the virus than other aforementioned industrialized countries. Nevertheless, Iran has a long way to go to achieve complete control of the pandemic.

Because Iran is located among neighboring countries in a very high-risk area for many diseases, including tuberculosis, rabies, Crimean Congo fever, cholera, brucella, malaria, polio, and some others, it has been even more successful in controlling such 


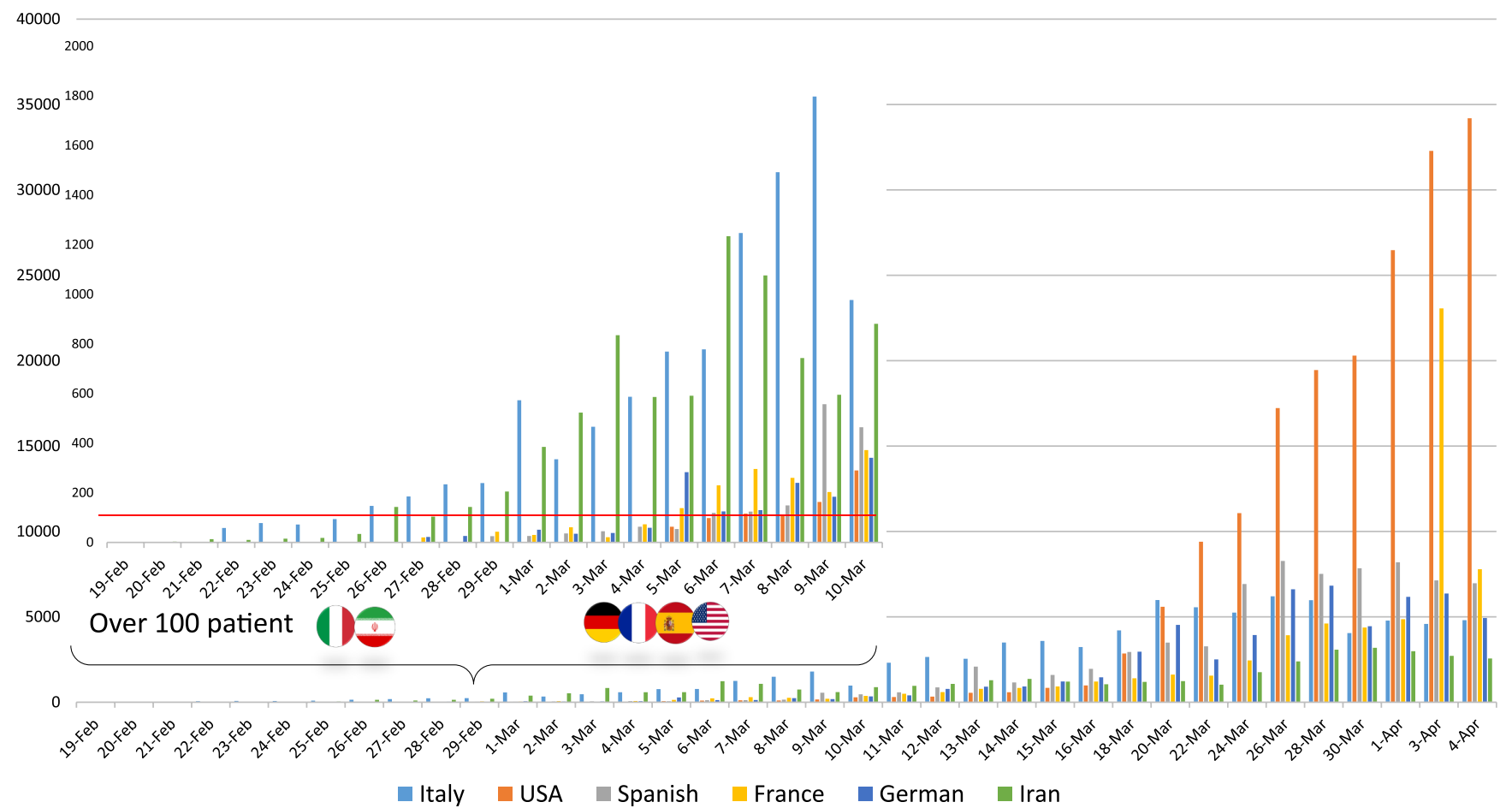

Fig. 1. Daily New Cases.

diseases than the United States. ${ }^{6}$ This experience and history are expected to be very useful and effective in controlling COVID-19.

Acknowledgments.

Financial support. No financial support was provided relevant to this article.

Conflicts of interest. All authors report no conflicts of interest relevant to this article.

\section{References}

1. Li Q, Guan X, Wu P, et al. Early transmission dynamics in Wuhan, China, of novel coronavirus-infected pneumonia. N Engl J Med 2020;382:1199-1207.

2. COVID-19 coronavirus pandemic. Worldometer website. https://www. worldometers.info/coronavirus/. Updated April 22, 2020. Accessed April 22, 2020.
3. Coronavirus disease 2019 (COVID-19) situation report-74. World Health Organization website. https:/www.who.int/docs/default-source/coronaviruse/ situation-reports/20200315-sitrep-55-covid-19.pdf?sfvrsn=33daa5cb_8. Published March 15, 2020. Accessed April 22, 2020.

4. Iranian Ministry of Health and Medical Education website [in Farsi]. http:// behdasht.gov.ir/. Published 2020. Accessed April 22, 2020.

5. Italian Ministry of Health and Medical Education [in Italian]. http://www. salute.gov.it. Published 2020. Accessed April 22, 2020.

6. Lohrasbi V, Mohammadzadeh N, Shirmohammadlou N. Brief outcome of five decades of battle with infectious diseases in Iran. Virus Dis 2020;31:10-12. doi: 10.1007/s13337-019-00565-y.

\title{
Might hydrogen peroxide reduce the hospitalization rate and complications of SARS-CoV-2 infection?
}

\begin{abstract}
Arturo A. Caruso $\mathrm{MD}^{1}$, Antonio Del Prete $\mathrm{MD}^{2}$, Antonio I. Lazzarino $\mathrm{PhD}^{3}$, Roberto Capaldi $\mathrm{MD}^{4}$ and Lucia Grumetto ${ }^{5}$
${ }^{1}$ Department of Otolaryngology, AIAS Structure of Afragola, Afragola, Naples, Italy, ${ }^{2}$ Department of Neurosciences and Reproductive and Dentistry Sciences, School of Medicine and Surgery, University of Naples Federico II, Naples, Italy, ${ }^{3}$ EPISTATA - Agency for Clinical Research and Medical Statistics, London, United Kingdom, ${ }^{4}$ School of Medicine and Surgery, University of Naples Federico II, Naples, Italy and ${ }^{5}$ Pharm-Analysis and Bio-Pharm Laboratory, Department of Pharmacy, School of Medicine and Surgery, University of Naples Federico II, Naples, Italy
\end{abstract}

To the Editor-The severe acute respiratory syndrome coronavirus 2 (SARS-CoV-2) is the virus responsible for COVID-19, which emerged

Author for correspondence: Prof Lucia Grumetto E-mail: grumetto@unina.it Cite this article: Caruso AA, et al. (2020). Might hydrogen peroxide reduce the hospitalization rate and complications of SARS-CoV-2 infection?. Infection Control \& Hospital Epidemiology, 41: 1360-1361, https://doi.org/10.1017/ice.2020.170 in Wuhan, China, in December 2019. The current pandemic appears to be characterized by human-to-human transmission; it occurs through cough, sneeze, droplet inhalation, and direct contact of hands with mouth, nose, and eyes. The virus resides in the mucous membranes and it is transmitted through the saliva and the respiratory droplets. Although prevention of person-to-person transmission is the key to limiting the pandemic, so far, little 